\title{
偏心環状流路における届流熱伝達*
}

\author{
鈴木 健二郎*1，Janusz S. Szmyd*2，大 塚 弘 雅 ${ }^{* 3}$
}

\section{Laminar Forced Convection Heat Transfer in Eccentric Annuli}

\author{
Kenjiro SUZUKI, Janusz S. SZMYD and Hiromasa OHTSUKA
}

\begin{abstract}
Numerical computation has been carried out for the laminar forced convective heat transfer in eccentric annuli. The finite difference equivalents of the governing equations of velocity and temperature fields written with a bipolar coordinate system were solved with an iterative procedure. A study has been made for two types of the second kind of thermal boundary conditions. The friction coefficient and average Nusselt number obtained were found to agree with the results previously reported by others. This validates the present computational method. The obtained cross-sectional distributions of velocity and of temperature, and the peripheral distributions of wall temperature and of local Nusselt number were discussed in detail. When the radius ratio is rather close to unity and eccentricity is large, the peripheral distributions of the friction coefficient and the local Nusselt number are remarkably nonuniform in relation to the conspicuous nonuniformity of velocity in the eccentric annulus. The local Nusselt number then takes a negative value in some regions. The wall temperature there is lower than the fluid bulk mean temperature because of a large peripheral nonuniformity of wall temperature. The temperature field in some cases is significantly far from axisymmetry.
\end{abstract}

Key Words: Convective Heat Transfer, Eccentric Annuli, Laminar Flow Regime, Local Nusselt Number, Local Wall Shear Stress

\section{1. 紼}

著者の一人は、これまで乱流プラントル数を導入し ない乱れモデル(1)を用いて，円管内(2)および同心環状 流路内 ${ }^{(3)}$ の液体金属中の乱流熱伝達を取扱い,さらに その延長として, 偏心環状流路内の乱流熱伝達を取扱 った ${ }^{(9)}$. 本報では，その準備として行った偏心環状流 路内の層流熱伝達の結果を報告する。

偏心環状流路内の, 流体力学的ならびに熱的に十分 に発達した首流熱伝達については、これまでにもいく つかの報告例がある．しかしそれらの例では管壁全周 にわたる平均ヌセルト数の検討が主体であるため，著 者の知る限りでは局所熱伝達に関する具体的な情報の 提供は必ずしも十分でない状況にある。そこで本報で は，一様熱流束で内筒面あるいは外筒面を加熱する場 合の局所熱伝達特性について検討を行った。

*平成元年 6 月 1 日 第 26 回日本伝熟シンホジウムに括て 講演. 原稿受付平成 2 年 2 月 2 日.

*1 京都大学工学部（６06 京都市左京区吉田本町）。

*2 St. Staszic Univ. of Mining and Metallurgy. Krakow. Poland.

*: 京都大学大学院 (現在関西電力(株) 姬路発電所].

\section{2. 壾号}

$$
\begin{aligned}
& A \text { : 流路断面棲 } \mathrm{m}^{2} \\
& a: \text { 温度伝尊率 } \mathrm{m}^{2} / \mathrm{s} \\
& C_{p}: \text { 定圧比熱 } \mathrm{kJ} /(\mathrm{kg} \cdot \mathrm{K}) \\
& d \text { : 偏心量（軸間距離） } \mathrm{m} \\
& D_{h} \text { : 水力直径 }=2\left(R_{o}-R_{i}\right) \mathrm{m} \\
& e: \text { 偏心率 }=d /\left(R_{o}-R_{i}\right) \\
& f: \text { ファニングの摩擦係数 } \\
& =(-d P / d z) \times D_{h} /\left(2 \rho U_{m}^{2}\right) \\
& \overline{N u_{k}}: k(=i, o) \text { 面の平均又セルト数 } \\
& =\left|q_{k}\right| D_{h} \mid \lambda\left(\overline{T_{k}}-T_{b}\right) \\
& N u_{k}\left(\theta_{k}\right): k(=i, o) \text { 面の局所又セルト数 } \\
& =\left|q_{k}\right| D_{h} / \lambda\left[T_{k}\left(\theta_{k}\right)-T_{b}\right] \\
& q \text { : 熱流束 } \mathrm{W} / \mathrm{m}^{2} \\
& P \text { : 压力 } \mathrm{Pa} \\
& R \text { : 半径 } \mathrm{m} \\
& R e \text { :レイノルズ数 }=U_{m} D_{h} / \nu \\
& T \text { : 温度 } \mathrm{K} \\
& U: \text { 流速 } \mathrm{m} / \mathrm{s} \\
& z \text { :軸方向座標 } \mathrm{m} \\
& \alpha \text { : 内外筒半径比 }=R_{i} / R_{o} \\
& \theta \text { : 角度（図 1） rad }
\end{aligned}
$$


$\nu:$ 流体動粘性係数 $\mathrm{m}^{2} / \mathrm{s}$

$\lambda:$ 流体熱伝迹率 $\mathrm{W} /(\mathrm{m} \cdot \mathrm{K})$

$\rho:$ 流体密度 $\mathrm{kg} / \mathrm{m}^{3}$

$\tau:$ せん断応力 $\mathrm{Pa}$

添 字

$$
\begin{aligned}
b & : \text { バルク (流体混合平均) } \\
i & : \text { 内筒外表面 } \\
m & : \text { 断面内平均 } \\
o: & : \text { 外筒内表面 } \\
- & : \text { 全周平均 }
\end{aligned}
$$

\section{3. 计算 法の概 要}

本研究では, 断面内二次流がない流体力学的, 熱的 に十分発達した偏心環状流路内の定常な首流熱伝達を 取扱う。流体は非圧縮性ニュートン流体で,プラント ル数の值は問わないが, 物性值は一定とする。流体に は，物体力は作用せず，流体中で相変化や化学反応は 生じないものとする，解析に使用する基礎式は，連続 の式，運動方程式およびエネルギー式であり，それら は直交デカルト座標系に対しては次のように書ける。

$$
\begin{aligned}
& \frac{\partial U_{i}}{\partial x_{i}}=0 \\
& U_{j} \frac{\partial U_{i}}{\partial x_{j}}=-\frac{1}{\rho} \frac{\partial P}{\partial x_{i}}+\frac{\partial}{\partial x_{j}}\left(\nu \frac{\partial U_{i}}{\partial x_{j}}\right) \\
& U_{j} \frac{\partial T}{\partial x_{j}}=\frac{\partial}{\partial x_{j}}\left(a \frac{\partial T}{\partial x_{j}}\right)
\end{aligned}
$$

本研究で取扱う流路形状を図 1 (a)に，また解析に 使用する双極座標 $(\xi, \eta)$ を図 1 (b)に示した。ここ で, $\xi=\xi_{0}$ は外筒の内表面 (以下外筒面)， $\xi=\xi_{i}$ は内 筒の外表面 (以下内筒面) に相当する. また $\eta=0$ は流 路が最も広い $\theta_{i}=\theta_{o}=0$ の位置に, $\eta=\pi$ は流路の最 狭部 $\theta_{i}=\theta_{o}=\pi$ に相当し，いずれも速度場，温度場の 対称面である。使用した双極座標 $(\xi, \eta)$ と図 1 (a)に 図示した直角座標系 $(x, y)$ の関係は次式で記述され る.

$$
\begin{aligned}
& x=-B \frac{\sinh \xi}{C_{s}} \\
& y=B \frac{\sin \eta}{C_{s}}
\end{aligned}
$$

ただし，

$$
\begin{aligned}
& C_{s}=\cosh \xi-\cos \eta \\
& B=\frac{1}{2 d} \sqrt{\left(R_{o}^{2}+R_{i}^{2}-d^{2}\right)^{2}-4 R_{o}^{2} R_{i}^{2}}
\end{aligned}
$$

上記の基礎式を双極座標を用いて書き直すと次のよう になる。

$$
\frac{\partial U}{\partial z}=0
$$

$$
\begin{aligned}
& \frac{1}{\rho} \frac{\partial P}{\partial z}=\frac{1}{B^{2}}\left[C \frac{\partial}{\partial \xi}\left(C \nu \frac{\partial U}{\partial \xi}\right)+C \frac{\partial}{\partial \xi}\left(S \nu \frac{\partial U}{\partial \eta}\right)\right. \\
& \quad+S \frac{\partial}{\partial \eta}\left(C \nu \frac{\partial U}{\partial \xi}\right)+S \frac{\partial}{\partial \eta}\left(S \nu \frac{\partial U}{\partial \eta}\right) \\
& \quad+S \frac{\partial}{\partial \xi}\left(S \nu \frac{\partial U}{\partial \xi}\right)-S \frac{\partial}{\partial \xi}\left(C \nu \frac{\partial U}{\partial \eta}\right) \\
& \left.\quad-C \frac{\partial}{\partial \eta}\left(S \nu \frac{\partial U}{\partial \xi}\right)+C \frac{\partial}{\partial \eta}\left(C \nu \frac{\partial U}{\partial \eta}\right)\right] \cdots \cdots(7) \\
& U \frac{\partial T}{\partial z}=\frac{1}{B^{2}}\left[C \frac{\partial}{\partial \xi}\left(C a \frac{\partial U}{\partial \xi}\right)+C \frac{\partial}{\partial \xi}\left(S a \frac{\partial U}{\partial \eta}\right)\right. \\
& \quad+S \frac{\partial}{\partial \eta}\left(C a \frac{\partial U}{\partial \xi}\right)+S \frac{\partial}{\partial \eta}\left(S a \frac{\partial U}{\partial \eta}\right) \\
& \quad+S \frac{\partial}{\partial \xi}\left(S a \frac{\partial U}{\partial \xi}\right)-S \frac{\partial}{\partial \xi}\left(C a \frac{\partial U}{\partial \eta}\right) \\
& \left.\quad-C \frac{\partial}{\partial \eta}\left(S a \frac{\partial U}{\partial \xi}\right)+C \frac{\partial}{\partial \eta}\left(C a \frac{\partial U}{\partial \eta}\right)\right] \cdots \cdots(8)
\end{aligned}
$$

ただし， $\boldsymbol{z}$ は軸方向座標，Uは方向の速度成分で あり，式(7)，(8)にはすでに式(6)が考慮されてお り、また

$$
\begin{aligned}
& C=\cosh \xi \cos \eta-1 \\
& S=\sinh \xi \sin \eta
\end{aligned}
$$

である。

式(7)および式(8)を文献 (4)に従って差分化し, 得られた差分方程式を数值解析によって解いた。計算 にあたっては，計算の開始時点では流れのレイノルズ 数を末知量として取扱った。すなわち，入力として圧 力こう配の值を与え，そ机に見合う壁面せん断応力分 布を生じる適切な流路内の速度分布を，反復計算によ って決定し, 得られた結果から断面内平均流速を求め, レイノルズ数を評価した。このとき，関係式

$$
\begin{aligned}
& \left(2 \pi R_{i} \overline{\tau_{i}}+2 \pi R_{o} \overline{\tau_{o}}\right) \\
& \quad=-\pi\left(R_{o}^{2}-R_{i}^{2}\right)(d P / d z)
\end{aligned}
$$

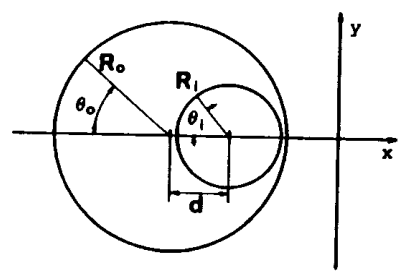

(a)偏心環状流路

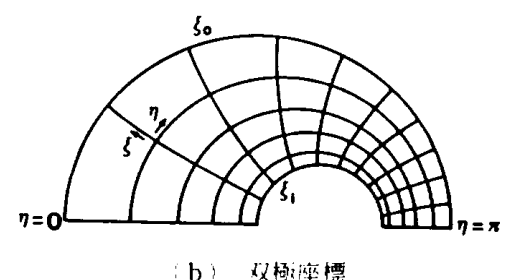

図 1 計算対象とした流路と座標系 
を使用した．各反復回の計算には 3 項方程式に対する 演算法を使用する line-by-line 法(4)を用いた。 $\xi$ - $\eta$ 面 内には格子点は等間隔に配置し，総格子点数は $50 \times 50$ 個とした。

境界条件としては，運動方程式に対しては内外壁面 上 $\left(\xi=\xi_{0}, \xi=\xi_{i}\right)$ で速度を零, $\eta=0, \pi$ では $\eta$ 方向の こう配を零とした。エネルギー式に対しては 2 種類の 第 2 種境界条件 ${ }^{(5)}$ に対して計算を実行した。その第 1 は内筒面熱流束が周方向と軸方向に共に一様 $\left(q_{i}=-\right.$ 定)で, 外筒面は断熱 $\left(q_{o}=0\right)$ されている場合, その第 2 は外筒面熱流束 ( $q_{o}=$ 一定) が周方向と軸方向の両 方向に一様で，内筒外表面が断熱 $\left(q_{i}=0\right)$ されている 場合である，以下では，前者を境界条件 $\mathrm{A}$ ，後者を境 界条件 B と呼ぶことにする。なお，式 (8) 中の温度こ う配 $(d T / d z)$ はバルク温度の $z$ 方向変化率と等しい から，

$$
(d T / d z)=2 R_{k} q_{\star} / \rho C_{p} U_{m}\left(R_{o}^{2}-R_{i}^{2}\right) \cdots
$$

により定められる。ただし，それぞれの境界条件に対 応して $k=i も し く は ~ k=o$ とする。 また，両境界条件 の場合とも $\eta=0, \pi て ゙ は \eta$ 方向の温度こう配は零と した。なお，物性值を一定とした取扱いをするので，以 下の議論は流体を加熱する場合にも，冷却する場合に も適用できる。

\section{4. 計算結果および考察}

$4 \cdot 1$ 従来の結果との对比 まず，これまで報告 例のある偏心環状流路全体に対する摩擦係数扔よび伝 熱面全周にわたる平均ヌセルト数に注目する. 図 2 に 摩擦保数を示した。緱軸には摩擦係数とレイノルズ数 の積を取り, その内外筒半径比 $\alpha$ に対する変化を偏 心率 $e$ をパラメータとして示した。図 2 中には, Tiedt ${ }^{(7)}$

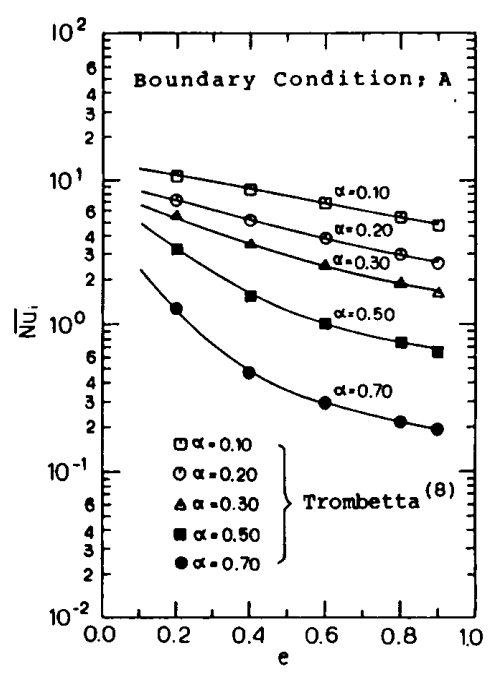

が求めた結果も示してあるが, 本計算値はそれと良好 な合致を示している. 図 3 に境界条件 A，B それぞれ の場合に得られた伝熱面全体の平均ヌセル卜数を示し た. 内外筒半径比 $\alpha$ が小さいほど，また偏心率 $e$ が小 さいほど，平均ヌセルト数は高い值を示すすすなわち， すきまが大きく，しかも同心環状流路に近い形状の流 路ほど平均熱伝達特性は良好である【したがって後の 議論で使用する温度差 $\left(T_{k}-T_{b}\right)$ は小さくなる). 図 3 中には Trombetta ${ }^{(8)}$ の結果をも提示したが, 今回の結 果とよく合致している。

図 4 に速度分布の計算例を鳥かん図的に示した。図 4 には内外筒半径比 $\alpha=0.1,0.3,0.5,0.7$ に対して偏 心率を 4 種類 $(e=0.2,0.4,0.6,0.8)$ に変えた場合の 結果が示してある。計算結果は，流路断面内で生じる 最大流速で規格化して図示されている。なおこれら の計算結果を Snyder-Goldstein の解析解 ${ }^{(6)}$ と比較し たところ，差異は最大 $0.1 \%$ \%った。 以上いずれの

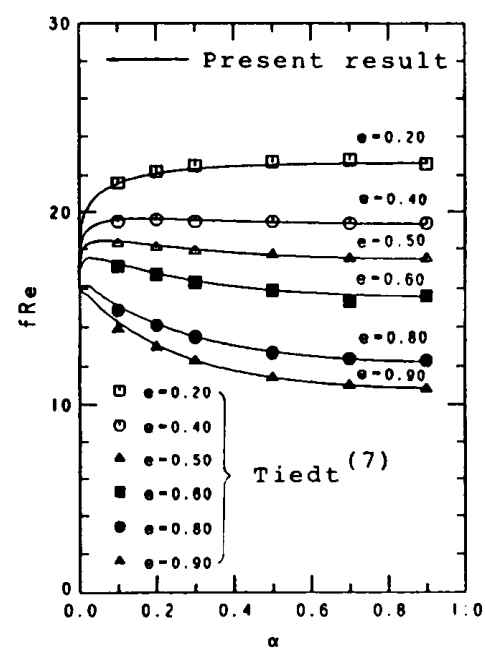

図 2 偏心環状流路全体の摩撩係数

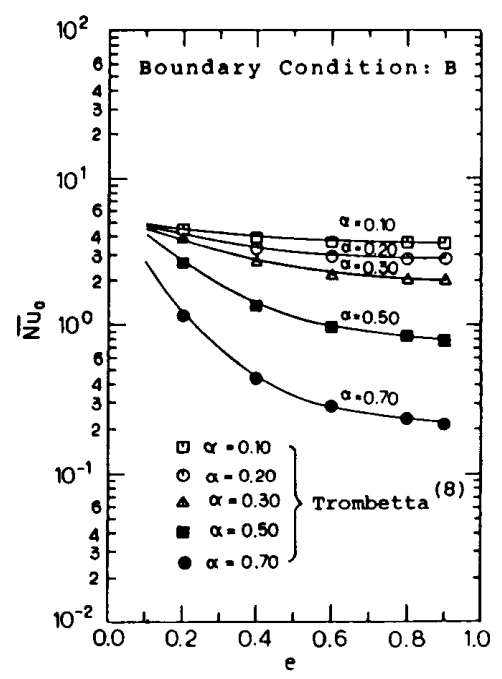

図 3 平均ヌッセルト数 
結果からも本研究で使用した数値解析手法は十分な精 度を有していると考えられる。そこで以下では諸量の 局所値につき検討を加える。

4 -2 流れ场の結果 図 4 を見ると,一般的に最 大速度は流路すきまが最大の位置 $(\eta=0)$ で生じ，ま た流路すきまが最も狭い部分 $(\eta=\pi)$ で流速は最も低 下している，最小すきま部の流速は，内外筒半径比 $\alpha$ が大きいほど低下し，また内外筒半径比 $\alpha$ が同じでも
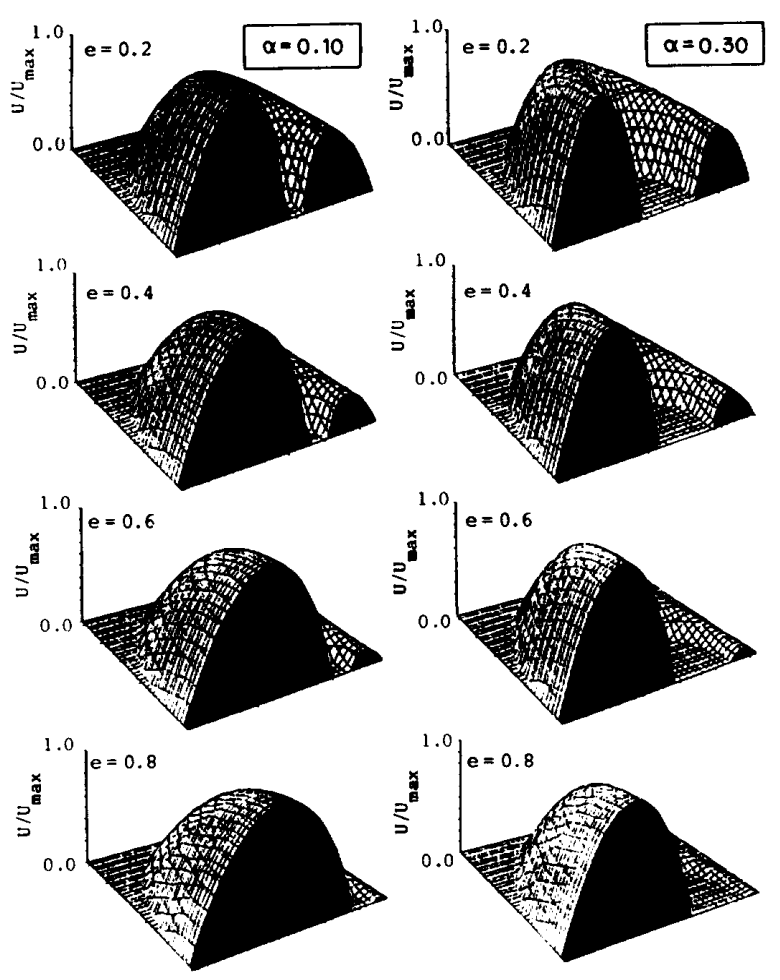

図 4 流路断面内の速度分布例
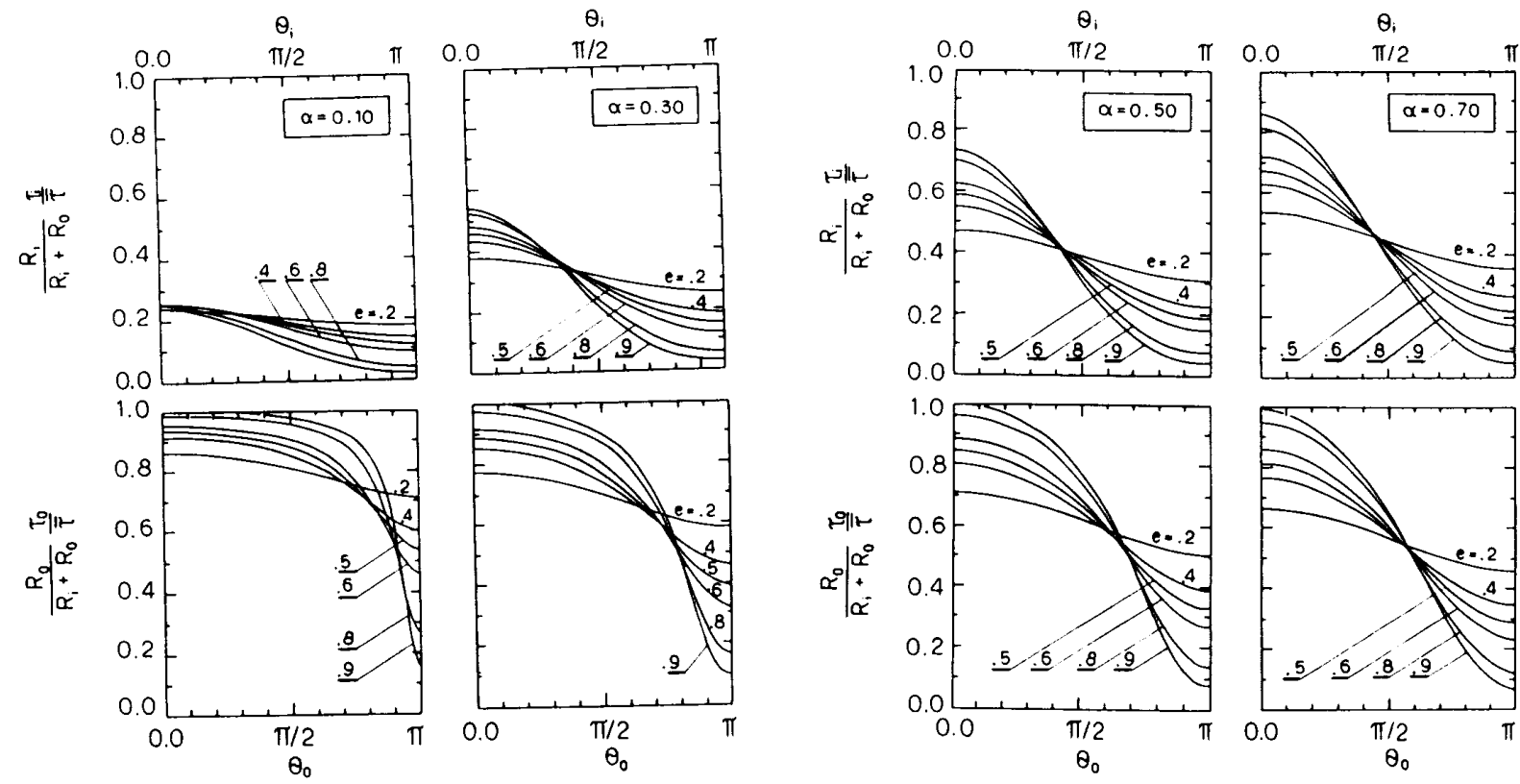

図 5 世ん断応力分布 
便宜を考えて, 各面と両面のぬれぶち長さの比を乗じ た值が示してある、 $\tau_{i}, \tau_{0}$ ともに最大すきま部で最大 值を取り，最小すきま部で最小值を示す点は，どの場 合にも共通している，偏心率が大きいほど最小すきま 部の $\tau_{i}, \tau_{o}$ が,より小さくなっている。また， $\alpha$ が小さ いほど,また $e$ がささいほど $\tau_{i}, \tau_{0}$ の分布は, より広 い範囲で平たんな形状を示す。一方 $\alpha$ が大きくなると $\tau_{i}, \tau_{o}$ の分布は互いに形状が類似し，絶対值の上でも 互いに近づく傾向を示している.

$4 \cdot 3$ 熱伝迲の結果 図 6 および図 7 に A, B 両 境界条件に対して計算された局所ヌセルト数と伝熱面 温度の周方向分布を示した.内外筒半径比が $\alpha=0.1$ の 場合には局所ヌセルト数, したがって局所伝熱面温度, は周方向に大きく変化しないが, $\alpha$ の値が大きくなる につれてその不均一が顕著になる.とくに $\alpha$ および $e$ の值が大きくなると, 前述のように平均ヌセルト数が 低下寸るから，逆に温度差 $\left(T_{k}-T_{b}\right)$ は拡大するので，
局所伝熱面温度の絶対值不均一は著しく顕著になる。 したがって、このような局所ヌセルト数および伝熱面 温度の不均一は，実際応用上問題となる場合が少なく ないが，それは従来の研究で検討主題とされてきた偏 心環状流路全体の平均ヌセルト数の結果からは推算で きないものである.

なお， $\alpha=0.5,0.7$ 場合には，eの值によっては境 界条件の種類にかかわらず, 最大すきま部に近い部分 で局所ヌセルト数 $N u_{i}\left(\theta_{i}\right), N u_{o}\left(\theta_{o}\right)$ が負となってい る.このことは，その位置の熱の移動方向 (熱流束の符 号）が局所ヌセルト数正の位置のそれと逆になること を示すものではない．伝熱面上の流体温度こう配は， もちろんどの位置でも熱の移動方向と対応する同じ符 号を有するが, 伝熱面温度の位置的変化が大きいので, 場所によっては $T_{k}\left(\theta_{k}\right)<T_{b}$ となり, 温度差 $\left[T_{k}\left(\theta_{k}\right)\right.$ $\left.-T_{b}\right]$ によって定義された局所ヌセルト数の符号が変 わるものである. 図 8 は流路断面内の流体温度 $[=\{T$
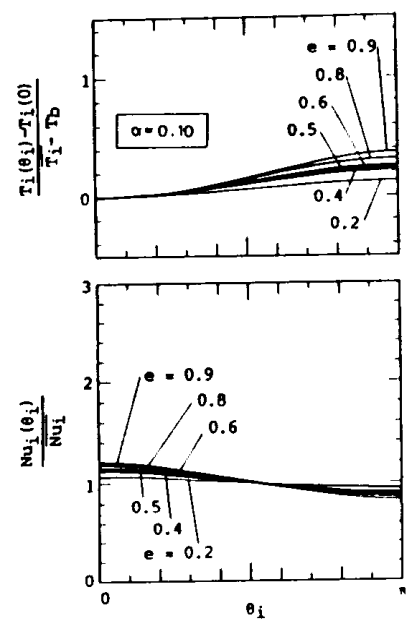

$\theta_{1}$
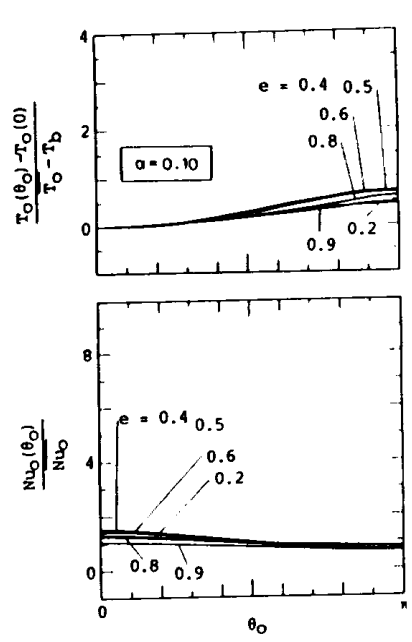
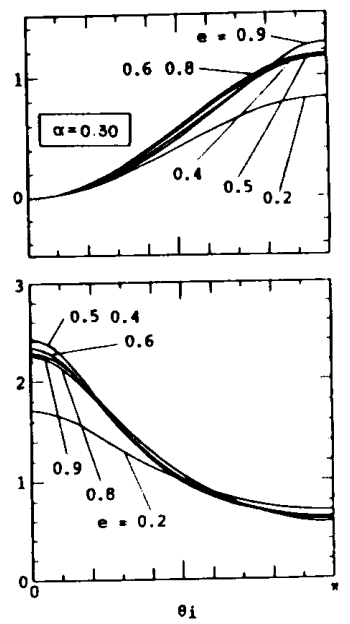

$\theta \mathbf{i}$
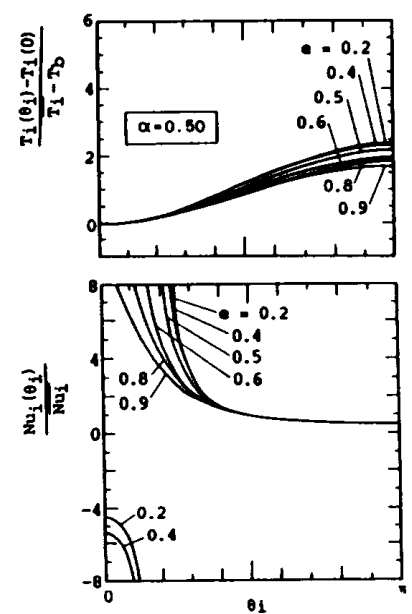
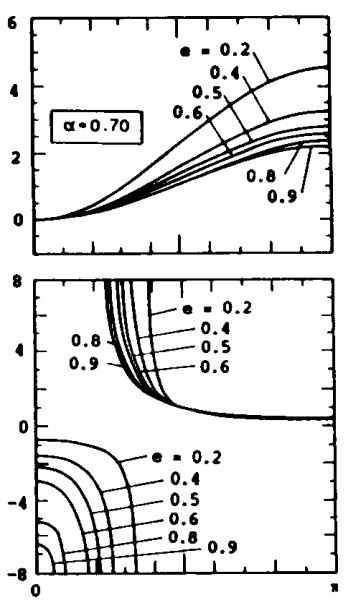

oi

図 6 局所ヌセルト数ちよび壁温の行布（境界条件 $\mathrm{A}$ )
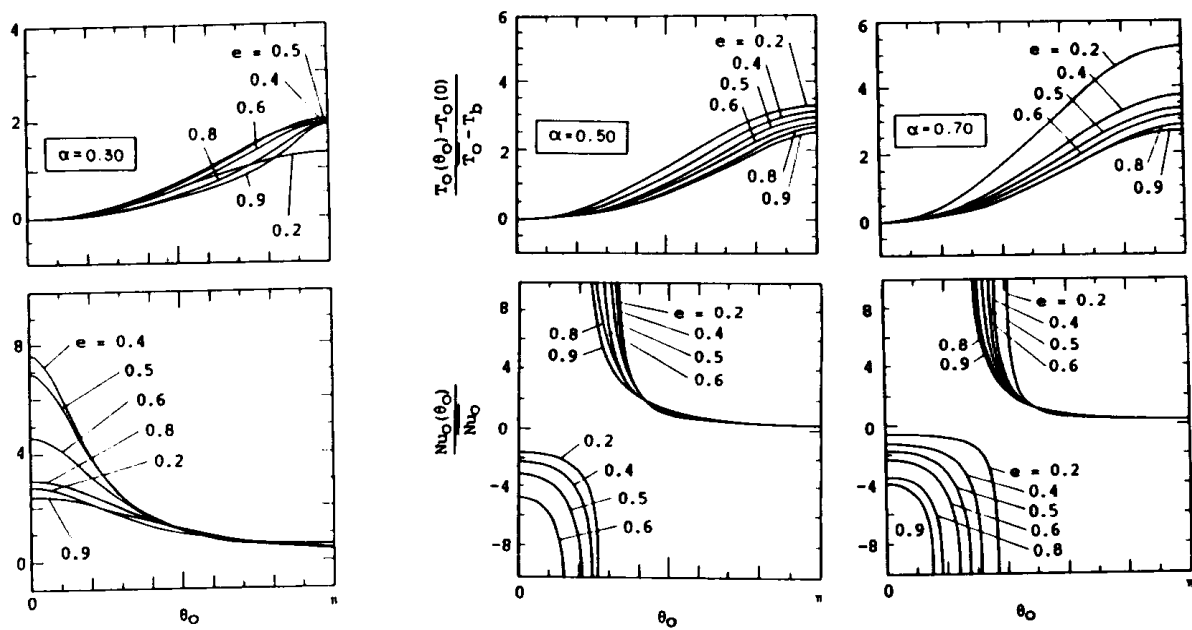

図 7 局所ヌセルト数および壁温の分布（境界条件 B） 

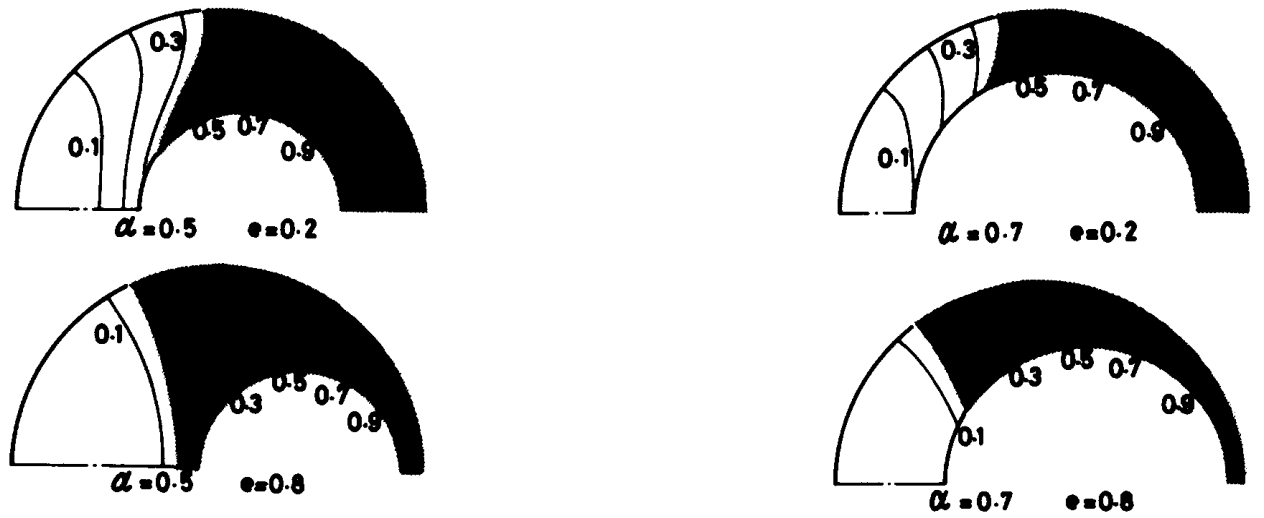

図 8 断面内流体温度分布の一例

$\left.\left.-T_{k}(0)\right\} /\left\{T_{k}(\pi)-T_{k}(0)\right\}\right]$ の分布例（境界条件 A) て ある. 図 8 中影を付した部分が $T \geqq T_{b}$ に相当するか ら, $T_{k}\left(\theta_{k}\right)<T_{b}$ となる部分の存在が確かめられる.同 心環状流路における軸対称温度分布に類似した分布 は， $\alpha$ および $e$ が共に小さい場合の最大寸きま部で多 少認められるものの, ヌセルト数分布の不均一が顕著 な場合には，それからほど遠い分布になっている，ま た最大すきま部では，いかなる条件下でも対流伝熱が 支配的で，かつ半径方向の熱移動が顕著であるのに対 し，最小すきま部では $\alpha$ おび $e$ の増大とともに流 速が減じて対流伝熱の寄与が低下し, しかも周方向熱 移動が顕著となるなど，両位置で伝熱機楼が互いに異 なっている， $\alpha$ と $e$ 変化に伴う局所ヌセルト数と局 所伝熱面温度の変化が, 最大すきま部と最小すきま部 で互いに異なっているのはこのためである。

図6，7では，場合により伝熱面温度の周方向不均一 が $\left(T_{k}-T_{b}\right)$ の数倍に及ぶことが認められるが, 図示 された最小すきま部の局所ヌセルト数を読取って，そ の場合の伝熱面最大温度を正確に評価することは困難 である. 熱伝達不良部分の伝熱面温度の評価のために は，局所ヌセルト数を提示するだけでなく，本論文の ように同時に局所壁温度を直接提示することが有用で ある。

なお，本研究では伝熱面熱流束一様の場合につき検 討を行ったが，実際には伝熱面内部で生じる熱伝導と 関連して，より複雑な境界条件下の問題を取扱う必要 があろう。そのような場合については別途の検討を必 要とするが, 図 8 の結果から次の点を指摘しておくこ とは有用であろう.すなわち $\alpha$ および $e$ が共に大きい 場合には, 周方向の伝熱面温度の不均一がより顕著に なるから，伝熱面内部で生じる周方向熱伝導したがっ て熱流束の周方向不均一度がより顕著となり、このた
めその場合に対する結果は, 本研究の結果からより大 きくずれるものと推察される。

\section{5. 結}

本研究では，偏心環状流路における層流熱伝達を双 極座標を用いて数值解析し，（1）流路全体に対する摩 擦係数と平均ヌセルト数を既存の結果と比較して, 計 算が十分な精度を有することを確認し，（2）速度と温 度の断面内分布, せん断応力と局所ヌセルト数の周方 向分布の数例を資料として提供し，これらの結果にも とづいて伝熱面温度の周方向不均一が $\left(T_{k}-T_{b}\right)$ の数 倍にも及ぶ場合があること，このため位置によっては 局所ヌセルト数が負になること，実用的には伝熱面温 度の直接提示が有用な情報となり得ること, を明らか にした。

\section{文献}

(1) Suzuki. K., Lett. Heat Mass Transt.., 9-4 (1982), 245254.

(2) Suzuki. K. and Tohkaku. A. (Bu-Xuan. Wang Heat Transfer Science' and Technology, (1987), 261-268.

(3) Suzuki, K., Tohkaku, A. and Sato. T., Proc. 8th Int. Heat Transf. Conf., 3 (1986), 969-9it.

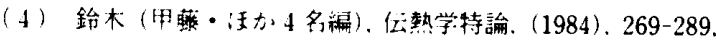
費贤堂.

(5) Shah. R. K. and London. A. L.. Adrances in Heat Transfer, Supplement, 1 (1978). Academic Press. New York.

(6) Snyder. W. T. and Goldstein. G. A.. AIChE. J., 11-3 (1965), $462-467$.

(7) Tiedt, II.. Chem. Appar. 91-1 (1967), 17-25.

(8) Trombetta. M. L.. Int. J. Heat Mass Transf., 14-8

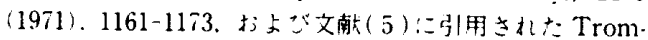
betta. M. L. t江私倍。

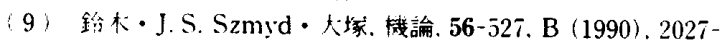
2033. 